\title{
Seventeenth-Century Jesuit Explorers' Maps of the Great Lakes and Their Influence on Subsequent Cartography of the Region
}

\author{
Carl Kupfer \\ Independent Scholar \\ carlkupfer@yahoo.com \\ David Buisseret \\ Senior Research Fellow, The Newberry Library \\ buisser@uta.edu
}

\begin{abstract}
When the French coureurs des bois and missionaries began to penetrate the interior of North America around the middle of the seventeenth century, they were confronted with a hydrological system of remarkable complexity, unique in the world. Some hints of the relationship of the five Great Lakes had been garnered by Samuel de Champlain in the early part of the century, but the western Great Lakes remained virtually unknown to Europeans about 1650. The delineation of this region was the work of four Jesuit-trained cartographers, whose work can (rather unusually) be completely traced from exploration to the original manuscript and then to the versions printed in Europe. It was in this way that French Jesuit maps came to form part of the North American cartographic image of many contemporary Europeans.
\end{abstract}

\section{Keywords}

Canada - New France - Claude Dablon - Claude Allouez - Jacques Marquette - JeanBaptiste Franquelin - Louis Jolliet - Jesuit cartography - Claude Delisle - Guillaume Delisle - Lake Superior 
When French settlers first began to establish themselves in North America, they were remarkably well served by mapmakers. The temporary bridgeheads established by Jacques Cartier and Jean-François de La Roque de Roberval in the early sixteenth century were convincingly shown in the maps of the Dieppe School, and the later establishment based on Québec (1608) was systematically charted by Samuel de Champlain. Whereas little is known of the life and formation of members of the Dieppe School, Champlain's cartographic formation with the French lodging-master's service is well understood, as is his ambiguous relationship with Henri IV (r.1589-1610). ${ }^{1}$ As the frontier of French expansion moved westwards, the Jesuit order provided the next group of leading cartographers. Whereas Champlain's cartography had come from his military experience, the expertise of the Jesuit cartographers has convincingly been attributed to the nature of the syllabus of the Ratio studiorum (Naples: Tarquinio Longo, 1598, promulgated 1599), with its emphasis on the importance of mathematics, cosmography and geography, which French Jesuit schools began to follow in the early seventeenth century. ${ }^{2}$

In the case of the four cartographers, Claude Allouez (1622-89), Claude Dablon (1619-97), Jacques Marquette (1637-75) and Jean-Baptiste Franquelin $(1650-c .1700)$, it is possible to be more specific about the nature of their formation, thanks largely to the work of the Père François de Dainville (1909-71) in the 1930s. No previous work attempted either to elucidate the origins of their skills, or to demonstrate the subsequent influence of their maps. Allouez, Dablon, Marquette and Franquelin (though the latter did not enter the order)

1 The fullest summary of the work of the Dieppe School is Sarah Toulouse, "Marine Cartography and Navigation in Renaissance France," in History of Cartography, 3/2, Cartography in the European Renaissance, ed. David Woodward (Chicago: University of Chicago Press, 2007), 1550-68. See also Chet Van Duzer, The World for a King:Pierre Descelier's Map of 1550 (London: British Library, 2015). For the seventeenth century, the many works of Conrad E. Heidenreich laid a foundation; see for example "Mapping the Great Lakes, The Period of Exploration, 1603-1700," Cartographica 17, no. 3 (1980): 32-64, as well as the atlases by W. P. Cumming et al., The Exploration of North America 1630-1776 (New York: G. P. Putnam, 1974), Derek Hayes, Historical Atlas of Canada (Seattle: University of Washington Press, 2002), and Raymonde Litalien et al., Mapping a Continent: Historical Atlas of North America 1492-1814 (Montreal: McGill University Press, 2007). For Champlain, see in particular Raymonde Litalien and Denis Vaugeois, eds., Champlain: The Birth of French America (Montreal: McGill/Queen's University Press, 2004).

2 See François de Dainville, S.J., Les Jésuites et l'éducation de la société française: La géographie des humanistes (Paris: Beauchesne, 1940); Denis de Lucca, Jesuits and Fortifications: The Contribution of the Jesuits to Military Architecture in the Baroque Age (Leiden: Brill, 2012); and Miguel de Asúa, Science in the Vanished Arcadia (Leiden: Brill, 2014). Chet Van Duzer and Lauren Beck, Canada before Confederation (Wilmington: Vernon Press, 2017) contains images and analyses of two maps of 1640 and 1651 , which may also be the work of the Jesuits. 
all attended French Jesuit colleges in the first half of the seventeenth century, where they were exposed to the general curriculum derived from the Ratio studiorum. This involved teaching mathematics in the first year of philosophy, and placed a high emphasis on the importance of geography, including maps. Even the smallest French Jesuit colleges were well supplied with libraries of maps, which served in particular to track the progress of Jesuit missions in various parts of the world and to encourage the ambitions of young scholars.

Those who had passed through the Jesuit curriculum had also often been exposed to the actual compilation of maps. In the parlance of the time, mapmaking was regarded as an aspect of "practical geometry." The principles of cartography taught in the schools were formalized in Father Jean François's (1582-1668) Géométrie pratique (1657). ${ }^{3}$ This book was studied not only by those hoping to become Jesuits, but also by other pupils who hoped to become army officers, for whom a mastery of elementary mapmaking was essential. Indeed, the ability to compose maps and plans of small areas was regarded as part of the normal skills of the honnette homme by the mid-seventeenth century. Sometimes such study was accompanied by technical exercises using instruments. At the Collège Du Puy, for instance, in 1616, a full discussion of "practical geometry" was accompanied by calculation of the latitude of Le Puy. ${ }^{4}$

Small wonder, then, that when French Jesuits reached Canada, or "New France," some of them proved to be masterly mapmakers. They not only knew the use of the magnetic compass and of the astrolabe (for calculating angles), but also were familiar with the recent efforts towards the use of magnetic variation methods for the calculation of latitude. Following efforts in the Spanish Empire, they even had strategies for calculating longitude, using heavenly phenomena simultaneously visible in France and in the New World, even if the challenges of weather and long-distance communication prevented them from actually making these calculations. ${ }^{5}$

3 Jean François, L'arithmétique et la géométrie pratique, c'est a dire, l'art de compter toutes sortes de nombres avec la plume et les jettons et l'art de mesurer tant de loing que de pres toute sorte de lignes, de surfaces, \& de corps: et particulierement d'arpenter les terres, \& d'en contretirer les plans. Et en suite de faire des cartes geographiques des dioceses, provinces, royaumes, \&c. hydrographyques des mers, rivieres, lacs, estangs, \&c. topographiques des villes, bourgs, chasteaux, forests, parcs, prez, champs, jardins, \&c. Par le P.Jean François, de la Compagnie de Jesus (Rennes: Pierre Hallaudays, 1657). For other Jesuit mathematics teachers in France see de Lucca, Jesuits and Fortifications, 188.

4 Dainville, Jésuites, 210.

5 For earlier Spanish efforts see Maria Portuondo, Secret Science: Spanish Cartography and the New World (Chicago: University of Chicago Press, 2009), 223-34; and Clinton Edwards, 


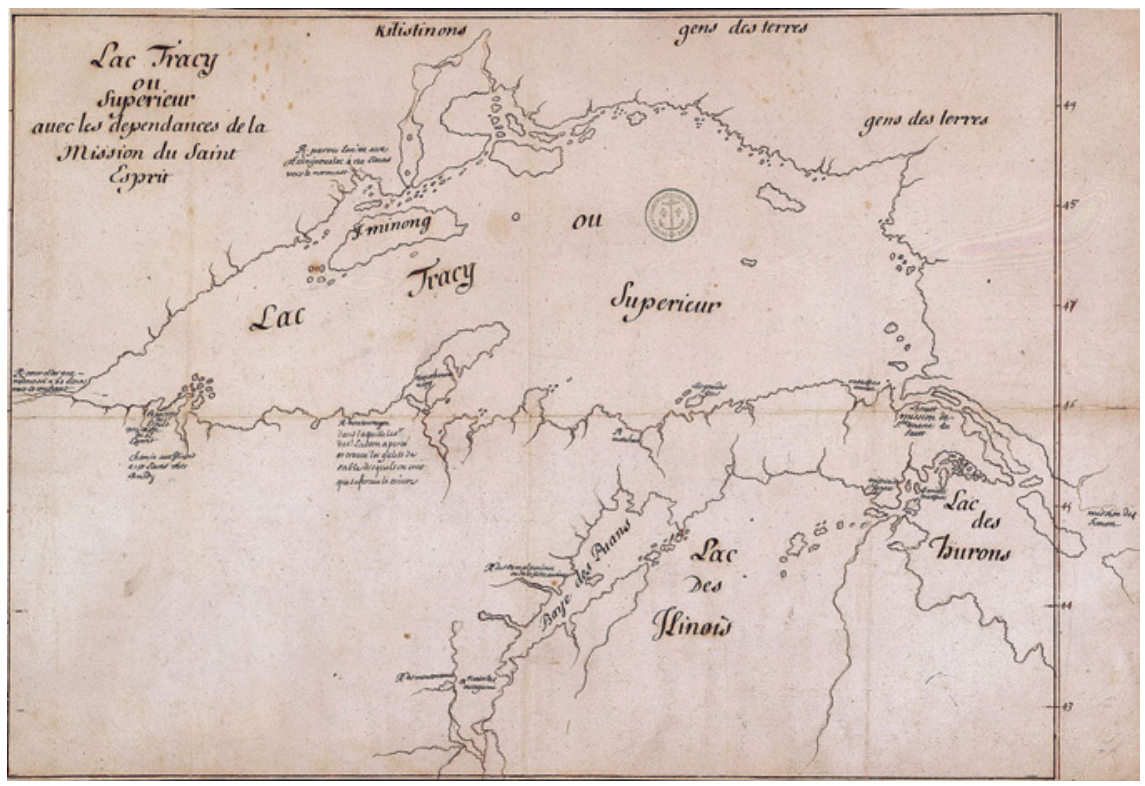

FIg U RE 4.1 Claude Allouez and Claude Dablon (attributed), Lac Tracy ou Superieur, avec les dependances de la Mission du Saint-Esprit (c.1668-89).

SERVICE HISTORIQUE DE LA DÉFENSE, DÉPARTEMENT MARINE, CARTES ET PLANS, R67 NO. 76

The influence of this new curriculum on the seventeenth-century French Jesuits can be seen in the great manuscript map of Lake Superior, drawn after 1668 probably by Allouez with some help from Dablon and perhaps another Jesuit (Figure 4.1). Between 1667 and 1669, Allouez had traveled the length and breadth of the lake, and explored the northernmost tributary rivers and lakes after his posting at the Mission La Pointe on Chequamegon Bay. ${ }^{6}$ Up until that

"Mapping by Questionnaire and Early Spanish Attempts to Determine New World Geographical Positions," Imago mundi 23 (1969): 117-208.

6 The map reproduced is Service historique de la Défense, département Marine, Cartes et plans, R67, no. 76. A second copy, perhaps a draft for the printer, is R67, no. 77. The map was published in two editions: Claude Dablon, Relation de ce qui s'est passé de plus remarquable aux Missions des Pères de la Compagnie de Jésus, en la Nouvelle-France, les années 1670 et 1671 (Paris: Sebastien Mabre-Cramoisy, 1672), 154; and Claude Dablon, Relation de ce qui s'est passé de plus remarquable aux Missions des Pères de la Compagnie de Jésus, en la Nouvelle-France, les années $1671 \& 1672$ (Paris: Sébastien Mabre-Cramoisy, 1673), between 110 and 111 . The 1673 version is reproduced by R. G. Thwaites, The Jesuit Relations and Allied Documents 55 (Cleveland: Burrows Brothers, 1896-1901), facing 94, [henceforth abbreviated as $J R$ ]. It can be found on the Newberry Library website, http://collections.carli.illinois.edu/cdm/ref/collection/ nby_eeayer/id/3494, accessed May 30, 2018. The dedicatory letter in the 1672 Relation from 
time, European ideas about the shape and extent of Lake Superior had been very vague, but Allouez and perhaps Dablon now used their map-making skills to produce a map of the lake's complicated coastline that has long been praised by historians of cartography and is sometimes called "the Jesuit map."7 Their depiction of Lake Superior greatly exaggerated its size. Allouez reported in his journal for September 1665, edited by François Joseph le Mercier (160490) for the Jesuit Relation of 1666 and 1667, that its length is two hundred lieuës, and its greatest width eighty lieuës. ${ }^{8}$ These figures are approximately the equivalent of 720 and 320 statute miles, instead of the correct 347 and 155 statute miles.

This distortion is well illustrated by the crude map which was drawn by the French cartographers Claude (1644-1720) and Guillaume (1675-1726) Delisle. Among their papers is a group of drawings referred to as the "Delisle sketches," drawn using in part information derived from the various Jesuit

Dablon to the Provincial Jean Pinette, of the province of France, explains, "On trouvera au commencement de la Relation des Outaoüacs, une Carte, qui represente les lacs, les rivieres, \& les terres, sur lesquelles son établies les Mißions de ce pays-là. Elle a esté dreßée par deux Peres assez intelligents, tres-curieux, \& tres-exacts, qui n'ont rien voulu mettre que ce qu'ils on veu de leurs propres yeux" ("Epistre," unpaginated). One of these fathers was most likely Allouez. The map was attributed to Allouez and Marquette by Lucien Campeau, "Les Cartes relatives à la découverte du Mississipi par le P. Jacques Marquette et Louis Jolliet," Les Cahiers des dix 47 (1992): 41-9o, here 43-47; and to Allouez and Dablon by Jean Delanglez, "Franquelin, mapmaker," Mid-America 25 (1943): 29-74.

7 For instance, Louis Karpinski, in his Bibliography of the Printed Maps of Michigan (Lansing: Michigan Historical Commission, 1931), 99, "No one can examine this fine delineation of Lake Superior and the northern parts of Michigan and Huron without amazement at the amount of scientific exploration and careful observation which made it possible."

8 "Les Sauvages respectent ce Lac comme une Divinité, \& luy font des sacrifices, soit a cause de sa grandeur, car il a deux cents lieuës de long, \& quatre vingt au plus large..." [“Journal du voyage du Pere Claude Alloüez dans les pais des Outaoüacs," in Relation de ce qui s'est passé de plus remarquable aux Missions des Pères de la Compagnie de Jésus, en la Nouvelle-France, les années 1666 and 1667, ed. François Joseph le Mercier (Paris: Sebastien Mabre-Cramoisy, 1668), 35; JR 50:264]. Dablon himself later writes, "Ce Lac a presque la figure d'un Arc bandé, de plus de cent quatre-vingt lieuës de long: Le côté du Midy en est comme la corde, \& il semble que la flêche soit une grande Langue de terre, qui avance plus de quatre-vingt lieuës dans le large, en sortant de ce même côté du Sud, vers le milieu du Lac." [Claude Dablon, "De la Mission du Saint Esprit, à la pointe de Chagaouamigong, dans le lac Superieur: et premierement des pesches differentes dont il abonde," Relation de ce qui s'est passé de plus remarquable en la Nouvelle-France, en 1669 \& 1670 (Paris: Sébastien Mabre-Cramoisy, 1671), 3:22; JR, 54:148-49]. See Carl Kupfer and David Buisseret, "Supersizing Lake Superior," The Portolan 99 (2017): 496o, and esp. Appendix B. "Seventeenth-century Maps of North America with Graphic Scales." 


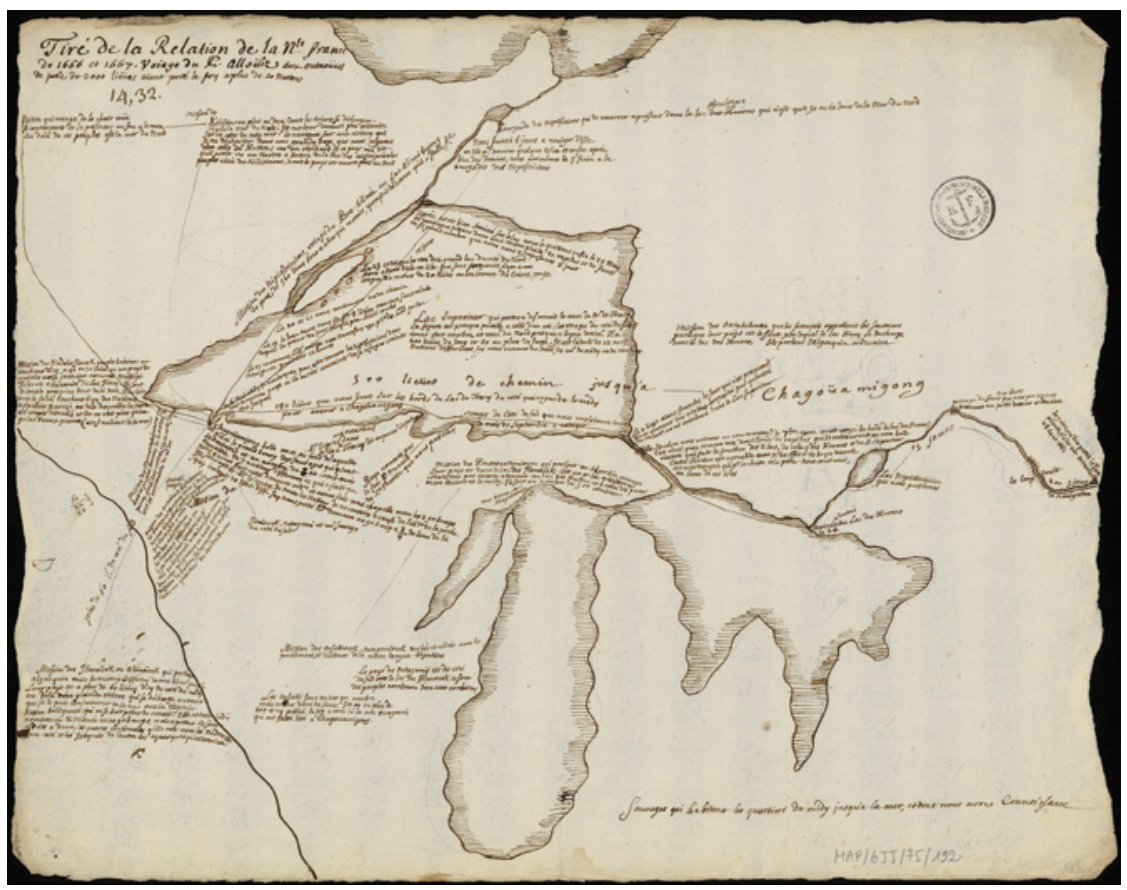

FIGURE 4.2A Claude and Guillaume Delisle, Tiré de la Relation de la Nle France de 1666 et 1667. Voyage du P. Alloüez dux Outaoüais de pres de 2000 lieües aians porté la foy aplus de 20 nations, Archives nationales de France, MAP, 6JJ/75/B, no. 192

Relations. ${ }^{9}$ Using the Relation of 1666 and 1667 , the Delisles note on their sketch (Figure 4.2A) that the figure from the eastern end of the lake to the mission at Saint-Esprit is 180 lieuës, to which approximately another twenty lieuës should be added to reach the western end of the lake, making two hundred lieuës (Figure 4.2B). The consequence of this exaggeration by Dablon is that on all of these maps, Lake Superior is shown about 2.6 times larger in surface area than it actually is.

A second map, delineating the upper Mississippi River, appears to have been the work of Jacques Marquette (Figure 4.3). The authenticity of this map, now in the Jesuit archives Montréal has been much disputed, in part because the river systems seem to be more precisely drawn than in previous manuscript

9 The "Delisle sketches" are Archives nationales de la République française, fonds Marine, cartes et plans, 6JJ/75, cartons A and B. See Nelson-Martin Dawson and Charles Vincent, L'atelier Delisle: l'Amérique du Nord sur la table à dessin (Quebec City: Éditions du Septentrion, 2000). 


\section{Southern shore of Lake Superior and Delisle annotations enlarged}

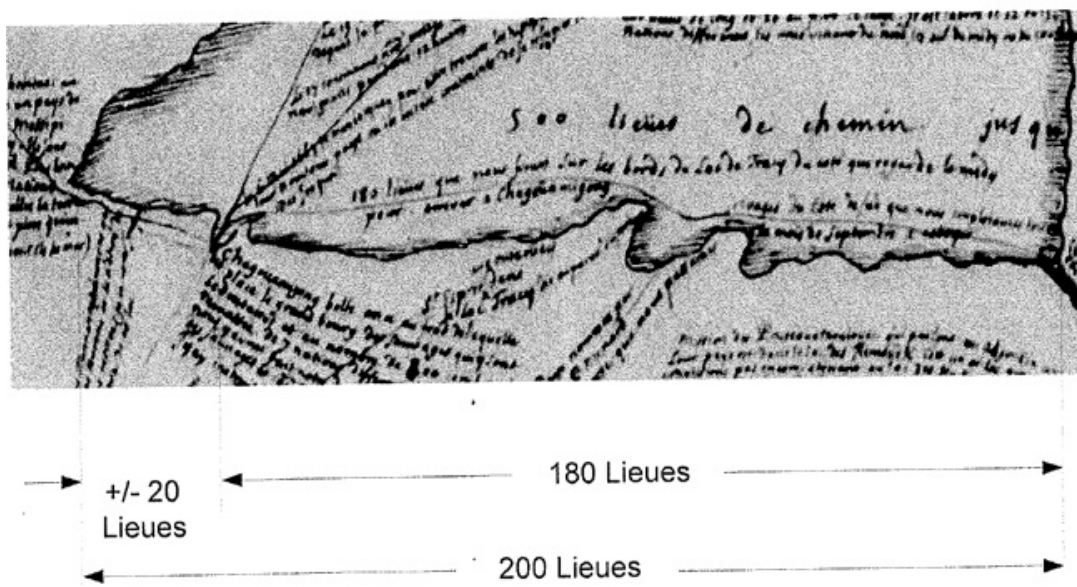

FIGURE 4.2B Enlargement of Figure 4.2A with annotated distance measurements along southern shore of Lake Superior

maps attributed in part to Marquette in the $\mathrm{BNF}$, which were subsequently published and popularized in a 1681 version by Melchisédec Thévenot (c.162092). And while the disputed Montreal map is thought to be solely the work of Marquette, the other maps in the BNF, which are labeled as "continuée par le R. Père Jacques Marquette," seem to be compilations that may or may not have been made by Marquette himself. ${ }^{10}$ Nevertheless, all of the maps in question

10 The manuscript BNF map (called the Manitoumie I map by Delanglez) is "Carte de la nouvelle découverte que les Rr. Pères Jésuites ont fait en l'année 1672 et continuée par le R. Père Jacques Marquette, de la mesme compagnie, accompagné de quelques François en l'année 1673 , qu'on pourra nommer la Manitoumie, à cause de la statue qui s'est trouvée dans une belle vallée et que les sauvages vont recon[n]oistre pour leur Divinité, qu'ils appellent Manitou, qui signifie Esprit, ou Genie," BNF, Cartes et plans, CPL GE C-5014, http:// gallica.bnf.fr/ark:/12148/btvib80o1827t, accessed May 31, 2018. A similarly-titled version (Manitounie II) is BNF, Estampes, Vd.31 83c 116493. A facsimile can be accessed through Vincas P. Steponaitis, "Early Maps of the American South--Special Topics: Early French Explorations" (November 13, 2017) http://rla.unc.edu/EMAS/topicsı.html\#Marq, accessed May 31, 2018. The Thévenot version entitled "Carte de la decouverte faite l'an 1673 dans l'Amerique Septentrionale" is from his Recueil des Voyages de Mr. Thevenot (Paris: Estienne Michallet, 1681). It can be seen at https://www.loc.gov/item/2006629776/ and https:// www.loc.gov/resource/g4042m.rbooooo5/, accessed May 31, 2018. The Montreal map first appeared with the discovery of Marquette's papers in 1844, and has been disputed as a possible nineteenth-century forgery by Félix Martin (1804-86). For the forgery case, see 
suggest skills that Marquette would have learned at Jesuit schools in Reims and Nancy, and as a teacher at several French Jesuit colleges between 1661 and 1665. They also reflect the increasing emphasis on learning Native American languages in the context of the mission itself. Marquette himself was ordered to study Algonquin languages, including Innu-aimun or Montagnais, almost immediately after his arrival in Quebec in September of 1666. In the summer of 1673, Marquette travelled with Louis Jolliet $\left(1645^{-1700}\right)$ from La Baie (Green Bay) down the Mississippi River near to the point where it joins the Arkansas River. Following the lead of Allouez and Dablon, on all of the maps Marquette carefully indicated the parallels of latitude, and he also set out the hydrographic features both of the lakes and of the Mississippi River with considerable accuracy, especially on the Montreal map. This was of particular importance because the Jesuit exploration of the region was essentially water-borne, almost exclusively using the lakes and their connecting rivers. Marquette also took care on all of the maps to mark in the general position of a large number of indigenous groups, taking advantage of his knowledge of Native American languages." This may also have been, as Asúa puts it, "geography at the service of religion."12 But while the "Jesuit map" of the western Great Lakes was primarily concerned to identify the best places for the founding of missions, Marquette set out the indigenous groups among whom missionary activity might flourish.

Marquette's companion on his great voyage of 1673 was Louis Jolliet, who afterwards provided information for a map constructed by Jean-Baptiste Franquelin, the leading mapmaker in Canada during the latter years of the seventeenth century. Franquelin's circa 1675 map (Figure 4.4) was much more elegant than Marquette's bare-bones effort. It lacked, however, the indigenous toponyms and also placed the north-south course of the Mississippi River about 200 miles too far to the west. Jolliet had to reconstruct this general topography from memory, after his canoe had been lost in the Saint Lawrence River, together with his papers. Curiously, Jolliet did have a sharp and accurate memory of the place where the Chicago River entered Lake Michigan.

Francis Steck, Marquette Legends (New York: Pageant Press, 1960). For the case that the map is authentic, see Jean Delanglez, "Marquette's Autograph Map of the Mississippi River," Mid-America 27 (1945): 30-35; and Carl Kupfer and David Buisseret, "Validating the 1673 'Marquette map," Journal of Illinois History 14 (2011): 261-76. The full reference is Archives des Jésuites au Canada, Montreal, $\mathrm{H}_{2} \mathrm{P} 1 \mathrm{~S} 6$. The general point of this paper is to place Jesuit cartography in the context of French Jesuit education and of parallel mapping efforts to other Jesuits as well as French cartographic efforts more broadly, questions that do not turn on the status of Marquette himself as a mapmaker.

11 Joseph Donnelley, Jacques Marquette (Chicago: Loyola University Press, 1985), 93-10o. 


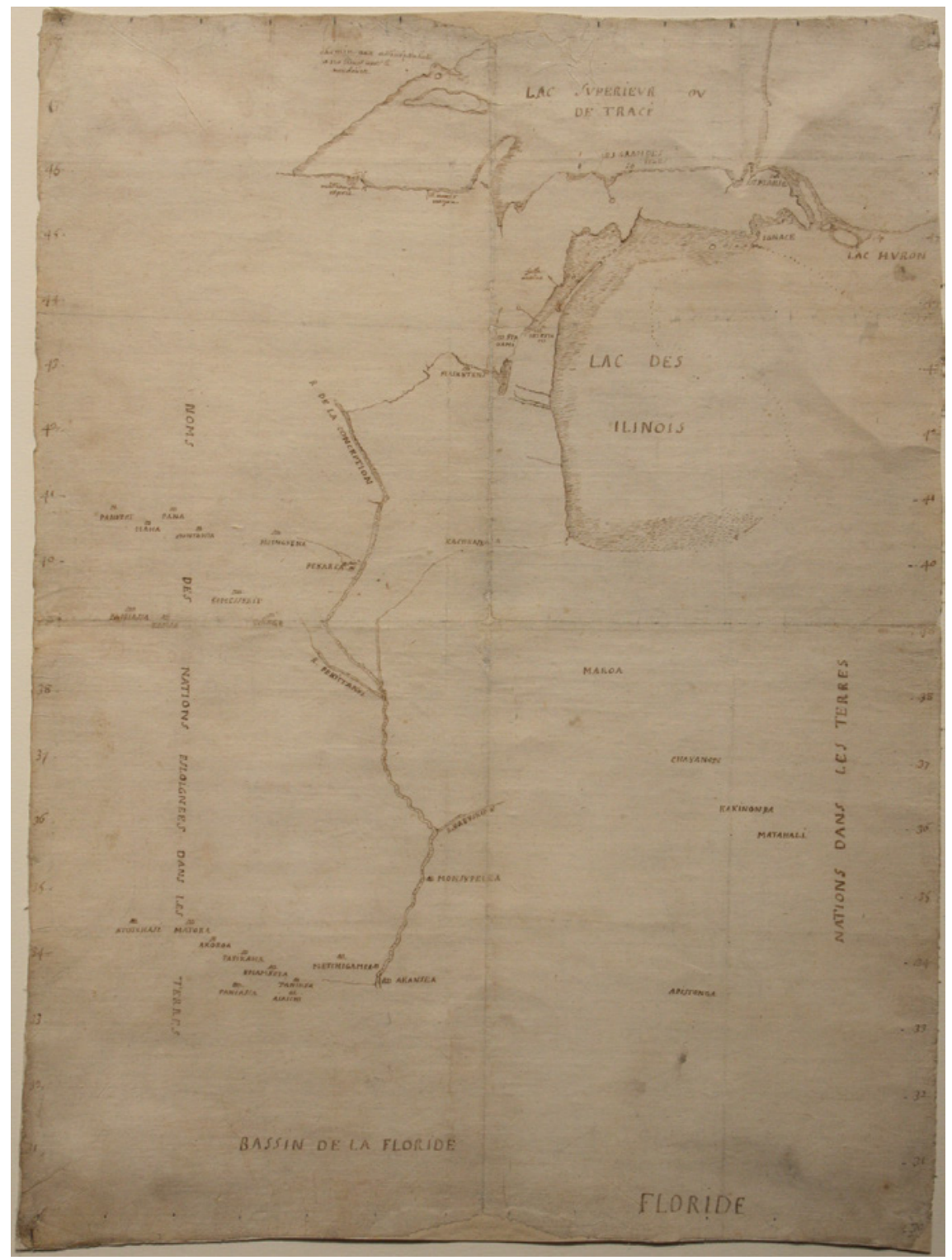

FIGURE 4.3 Jacques Marquette (attributed), Map of the Upper Mississippi River and Western Great Lakes, c.1674 ARCHIVES DES JÉSUITES AU CANADA, MONTRÉAL 
These three maps, in their various versions, varied greatly in their subsequent influence. The first "Jesuit map" of Lake Superior, accurately reproduced almost immediately in a manuscript copy and two printed copies, offered what became the generally accepted outline of the lake. The map's over-sizing of the lake was equally influential, so that maps of the area down to the end of the seventeenth century showed its excessive elongation from east to west. The resulting maps seriously distorted the central area of North America, perhaps contributing to the extraordinary westward displacement of the Mississippi River. The error would not be generally corrected until the work of Guillaume Delisle at the end of the century.

The significance of these distortions may be gauged by calculating the length of Lake Superior on seventeenth-century maps of North America with meridians of longitude. These range from 17 degrees of arc down to 7.7 degrees. 17 degrees gives a reading of about 780 miles, whereas 7.7 degrees gives only about 364 statute miles, close to the actual figure of $35^{\circ}$ miles. The 1688 map by the highly influential Venetian cartographer Vincenzo Maria Coronelli shows that following his calculations Lake Superior's western end lay at 278.5 degrees, and eastern end at 288 degrees, giving the figure of 9.5 degrees of longitude. Working from Italy, he still seems to have been under the influence of Dablon's supersized lake.

Although the Thévenot version of Marquette's journey was widely disseminated in multiple editions, Marquette's manuscript Montreal map only reappeared in the 1840 s, when it subsequently became famous through a number of reproductions. The thirty-three indigenous place-names found on maps of the 1670 s that had relied on Marquette, which differ on the Montreal and BNF maps, tended to fade out with the passage of time. Cartographers became less interested in missionary ventures among the tribes, and more tuned in to the requirements of the monarchy. Ethnographers have recently found these toponyms of great interest, recovering Marquette's interest in language. ${ }^{13}$ But Marquette's apparently more precise delineation of the Mississippi and Illinois rivers on the Montreal map would otherwise be lost, aside from the mapping of the Delisles at the end of the seventeenth century.

The map of Jolliet and Franquelin, by contrast, would remain much copied in Europe, particularly in its faulty delineation of the relationship between the Great Lakes and the Mississippi River. For instance, in his map Coronelli not only gives an excessive length to Lake Superior, but also follows Franquelin's westward displacement of the Mississippi River, so that it would emerge into

13 Michael McCafferty, Native American Place-Names of Indiana (Urbana: University of Illinois Press, 2008), 20. 


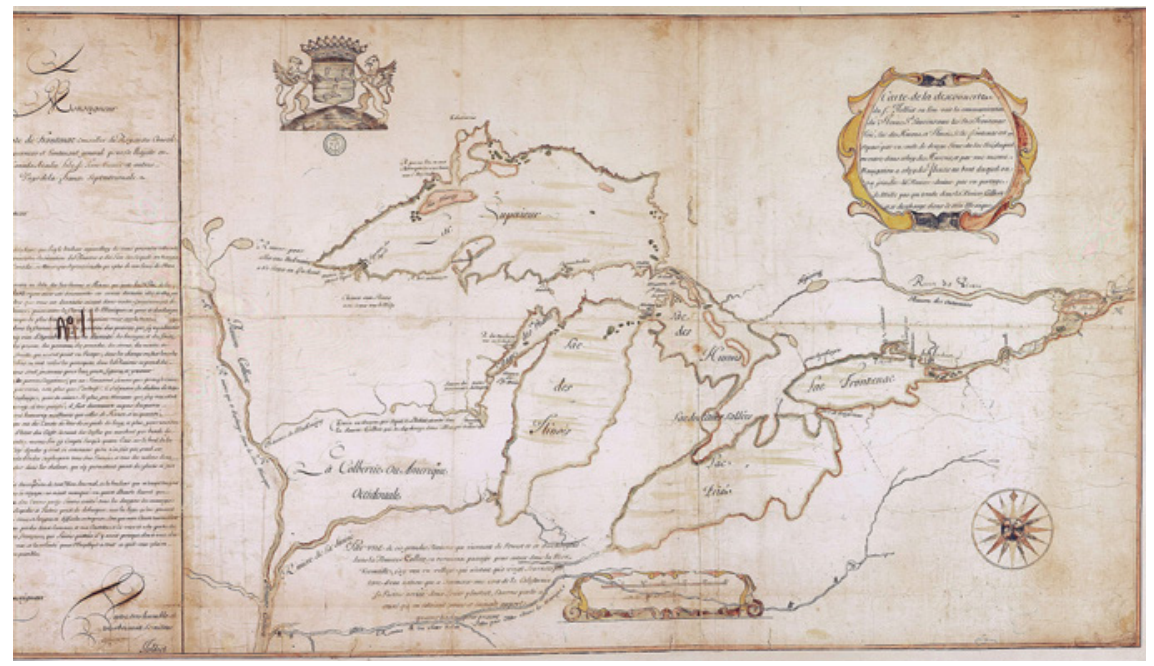

FIGURE 4.4 Louis Jolliet and Jean-Baptiste Franquelin, Carte de la descouverte du Sr. Jolliet ou l'on voit la communication du Fleuve St Laurens avec les Lacs Frontenac, Erié, Lac des Hurons, et Ilinois, le Lac Frontenac est separé par un sault de demye lieue du lac Erié, duquel on entre dans celuy des Hurons, et par une mesme Navigation a celuy des Ilinois au bout duquel on va joindre la Riviere divine par un portage de mille pas qui tombe dans la Riviere Colbert et se descharge dans te sein Mexique, (c.1675). SERVICE HISTORIQUE DE LA DÉFENSE, DÉPARTEMENT MARINE, CARTES ET PLANS, R67 NO. 39A

the Gulf of Mexico almost at the actual estuary of the Rio Grande. Even though La Salle had in fact reached the mouth of the Mississippi River on the Bay of Mexico many years earlier, his account was so cartographically inaccurate that even a skilled and well-informed cartographer like Coronelli could place the Mississippi River hundreds of miles west of its actual location, fed by an improbably long Illinois River, another legacy from Franquelin.

Jesuit exploration had cartographic effects beyond the maps they produced themselves. Towards the end of the seventeenth century, Claude and Guillaume Delisle began entirely revising the cartography of North America, using data generated partly from a close reading of the Jesuit Relations, and partly from astronomical observations. ${ }^{14}$ Unlike the polymath Thévenot, the Delisles were master tabulators, or "cartographes de cabinet," sometimes even using

14 For accounts of astronomical efforts in relation to cartography see Monique Pelletier, "The Working-Method of the New Cartographers," Terrae incognitae 34 (2002): 60-72; Lucie Lagarde, "Un cartographe face à ses sources: Guillaume Delisle (1675-1728) et l'Amérique du Nord," in Catherine Bousquet-Bressollier, L'oeil du cartographe (Paris: Comité des travaux historiques et scientifiques, 1995). 
explorers' texts to correct the explorers' very own maps. From the "Delisle sketches," preserved at the Archives nationales in Paris, it is possible to ascertain exactly which set of the Relations they were using in their cartographic calculations.

The Delisles drew their maps using information found in the Relations of 1639-40, 1657-58, 1659-6o, 1666-67, 1668-69, 1669-70, and 1667-71. On their map-commentary concerning the Relation of 1666 and 1667, for instance, they copied out the note by Allouez which observes that "having entered the southern coast, we spent the whole month of September in coasting along its southern shore" (Figure 4.2B). It is also on this map that is found the section concerning the shape of Lake Superior drawn from his journal, "The figure of this lake is nearly that of an arc, the southern shore being much curved, and those of the north nearly in a straight line."15 This interpretation of the shape of Lake Superior is best illustrated by the Delisles's map commentary on the Relation of 1670 and 1671 . It shows the lake almost resembling a bow, with the embayments of the southern shore largely flattened, and the Keewenaw Peninsula, as the arrow, greatly elongated (Figure 4.5). In fact, these maps were cartographic exercises for the Delisles, made to assess the information found in the Relations, while following the generally accepted outline of the map of 1668 (Figure 4.1). Using both information from the Relations and possibly a knowledge of the outline of the Marquette map for the rivers, they slowly came to a better understanding of the shape of the western Great Lakes.

They tied this information into a variety of astronomical observations as part of the second printing of the great Carte du Canada (Paris: Guillaume Delisle, 1700, 1703-18). On it, the estuary of the Mississippi River on the Bay of Mexico is for the first time correctly shown, following information derived from Pierre Le Moyne d'Iberville (1661-1706), who had ascertained the accurate position of the river's mouth in February 1699. Above the estuary may be seen the northward course of the Mississippi, running up to the "R. des Acansa," almost reached by Marquette in 1673 . To the north may be seen the "Village des

15 The texts on the Delisle map read: "rivage du cote du sud que nous emploiames tout le mois de Septembre a cotoyer" and "La figure est presque pareille a celle d'un arc, les rivages du coté du sud étant fort courbes et ceux du Nord presqúe en ligne droite." The texts from the printed Relations are slightly different: "Estans donc entrés dans le Lac de Tracy; nous employâmes tout le mois de Septembre á naviger sur les bords qui sont du costé du Midy" [“Journal du voyage du Pere Claude Alloüez dans les pais des Outaoüacs," in Relation de ... 1666 and 1667, 37; JR 50:266] and "La figure de ce lac est presque pareille à celle d'un arc, les rivages du costé du sud estant fort courbés, \& ceux du nord presque en droite ligne" [“Journal," 33-34; JR 50:264]. 


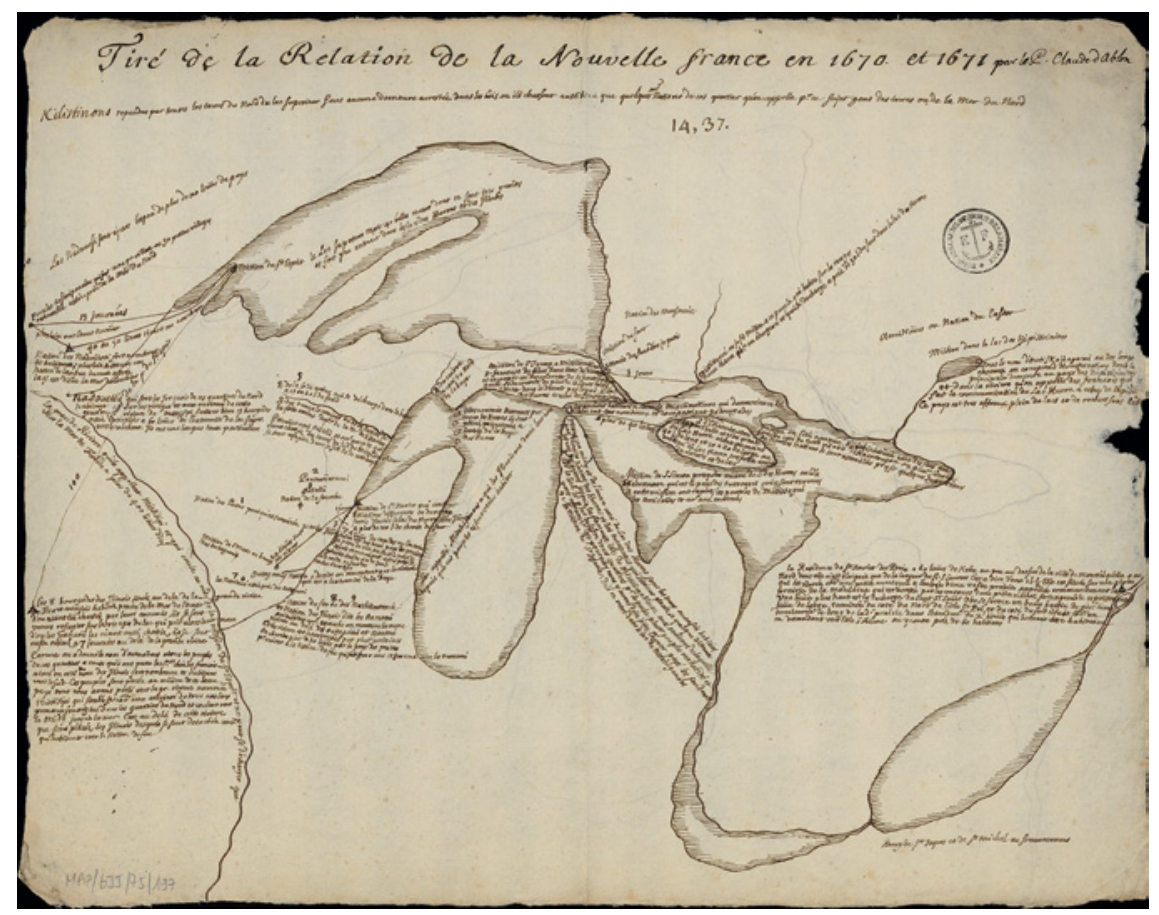

FIGURE 4.5 Claude and Guillaume Delisle, Tiré de la Relation de la Nouvelle France en 1670 et 1671 par le P. Claude Dablon, Kilistinons [Cree] repandus par toutes les terres du Nord du lac Superieur dans acune demeure arresteé dans les bois ou ils chassons aussi bien que quelques aux nations de cet quartier qúon appelle pr. ce sujet gens de terres ou de la Mer du Nord.

ARCHIVES NATIONALES DE FRANCE, MAP, 6JJ/75/B, NO. 197

Tamaroa," with the Illinois River flowing in from the north-north-east, following the distinctive course of the river plotted by Marquette. The "R. des Illinois" then curves sharply eastwards, to the point at which it approaches (to the left of "Miamis") the southward course of the Illinois River. Clearly, Delisle, unlike the early Jesuits, was not centrally interested in the hydrography linking the Great Lakes and the Mississippi. Indeed, it would be many years before cartographers reverted to an accurate description of this crucial area.

In the general perspective of Jesuit mapping of the New World, Allouez, Dablon, Marquette and Franquelin occupy a distinguished place. Their activity in the area of the Great Lakes was in a sense relatively simple to carry out, since it involved the establishment of a series of closed surveys (the shorelines of the five lakes), which could eventually be mapped with a fair degree of precision. They did not have to struggle with the problem of boundless deserts 
and inhospitable mountains, like Eusebio Kino in northern Mexico; nor were they attempting, like Samuel Fritz, to bring order to the immensely complex affluents of the River Amazon.

Paradoxically, it would seem that most of the Jesuit cartographers of central and south America came from central Europe, whose missionaries naturally sought fulfilment in the Spanish Habsburg territories across the Atlantic (and not, of course, in Portuguese Brazil). Jesuits of Spanish origin tended to congregate in the great cities like Lima, Bogota and Mexico City, while those from central Europe often went to the missions, as a list of their names attests. ${ }^{16} \mathrm{All}$ had at some stage followed the Ratio studiorum in Jesuit colleges of the Holy Roman Empire and the Habsburg domains, leaving them with skills that could easily be applied to the construction of maps. Like their French Canadian colleagues, they tended to compile maps showing not only the main physical features of their missionary territory but also the location of the indigenous groups among whom they and their successors might work. Most of these missionaries were investigating countries unvisited until then by Europeans, so their maps necessarily came out of what we call exploration. The maps analyzed in this paper allow the rare chance to follow the exact stages of their formulation, from the exploration of the land to the drawing of the manuscript map, to the generation of printed copies, and finally to the map's dissemination among a variety of readers.

16 David Buisseret, "Jesuit Cartography in Central and South America" in Jesuit Encounters in the New World, eds. Joseph Gagliano and Charles E. Ronan (Rome: Institutum Historicum S.I., 1997), 115. The abundance of mapmaking by Jesuits in Central and South America forms a body of work unrivalled by any other Order, and testifies in part to the influence of the Ratio studiorum, see for example Ernest Burrus La obra cartográfica de la provincia mexicana de la Compañía de Jesús (1567-1967) (Madrid: José Porrúa Turanzas, 1967) and Guillermo Furlong Cardiff, Cartografía jesuítica del Río de la Plata (Buenos Aires: Jacobo Peuser, 1936). 